\title{
Susumu and Swiss horses
}

\author{
H.P. Klinger \\ Department of Molecular Genetics, Albert Einstein College of Medicine, Bronx NY (USA) \\ Dedicated to Dr. Susumu Ohno on the occasion of his 70th birthday.
}

In Ulrich Wolf's laudatio to Susumu Ohno at the beginning of this volume he describes Susumu's love for horses and his equestrian skills as well as artistic talents. The present anecdote also relates to these attributes and I tell the story here because to my mind it demonstrates Susumu's inordinate and almost Zen-like control of his body by his mind. I suspect that this has much to do with his ability to concentrate very deeply on scientific problems and, as Ulrich also indicates, perform complex intellectual exercises or virtual experiments in his mind - his "Gedanken" experiments. As is inevitable, the conclusions from such Gedanken experiments on rare occasions turned out not to be completely correct. Despite this they contributed much to science because his exciting papers stimulated many other workers to pursue similar work and in the process of rectifying these errors they came up with important findings.

One day in 1961 while still a young instructor, I was surprised when Professor Gerhard Wolf-Heidegger, the head of the Department of Anatomy of the University of Basel School of Medicine in Switzerland, where I was working, called to tell me that Dr. Riojun Kinosita, Director of the Department of Experimental Pathology at the City of Hope Medical Center in Duarte California, was in his office and wanted to come to my laboratory to see me. I knew Dr. Kinosita only from the important cytologic and cytogenetic papers he was then publishing with Susumu (see for example Ohno et al., 1959; 1961a; 1961b). In response to Dr. Kinosita's request to tell him what I was working on I outlined my studies to him for perhaps 10 minutes. He then said. "I send my boy Susumu to work with you" and promptly took leave. I did not take this comment very seriously because it was delivered almost as a pleasantry and without any further discussion. I was consequently again surprised and delighted when a few months later a letter from Susumu indicated that he would be in Basel shortly.

It was a very exciting period in mammalian cytogenetics because the then recent techniques for looking at chromosomes led to many unexpected and important findings. Always well ahead of others, Susumu realized that to understand the events that led to these chromosome abnormalities required a much better knowledge of meiosis than was then available, particularly in respect to what happened during the embryonic stages. Even the knowledge that was available was contradictory (see Ohno et al., 1962 for details). Consequently Susumu decided that we should look at the gonads of human female embryos. We were in a very good position to do this in Basel since the Department of Anatomy had an excellent and extensive collection of very well prepared complete serial sections of human embryos at different developmental stages. In addition, very fresh embryos were occasionally available from the cooperative gynecological surgeons at the medical school when for medical reasons they had to interrupt pregnancies. Susumu immediately, and with great enthusiasm as well as with tremendous concentration started this work. I will come back to this later.

I soon learned that Susumu was very fond of horseback riding and that he did a considerable amount of dressage riding. I am not certain if at that time he already owned horses or if this came later. In any event, I thought he might be missing his riding and decided to remedy this. I asked friends who did a lot of riding to recommend a good stable where Susumu as an experienced equestrian would find good horses he would

Request reprints from Dr. H.P. Klinger, Department of Molecular Genetics, Albert Einstein College of Medicine, 1300 Morris Park Ave, Bronx NY 10461 (USA) telephone: 718-430-2451; fax:718-430-2454; e-mail: hklinger@aecom.yu.edu 


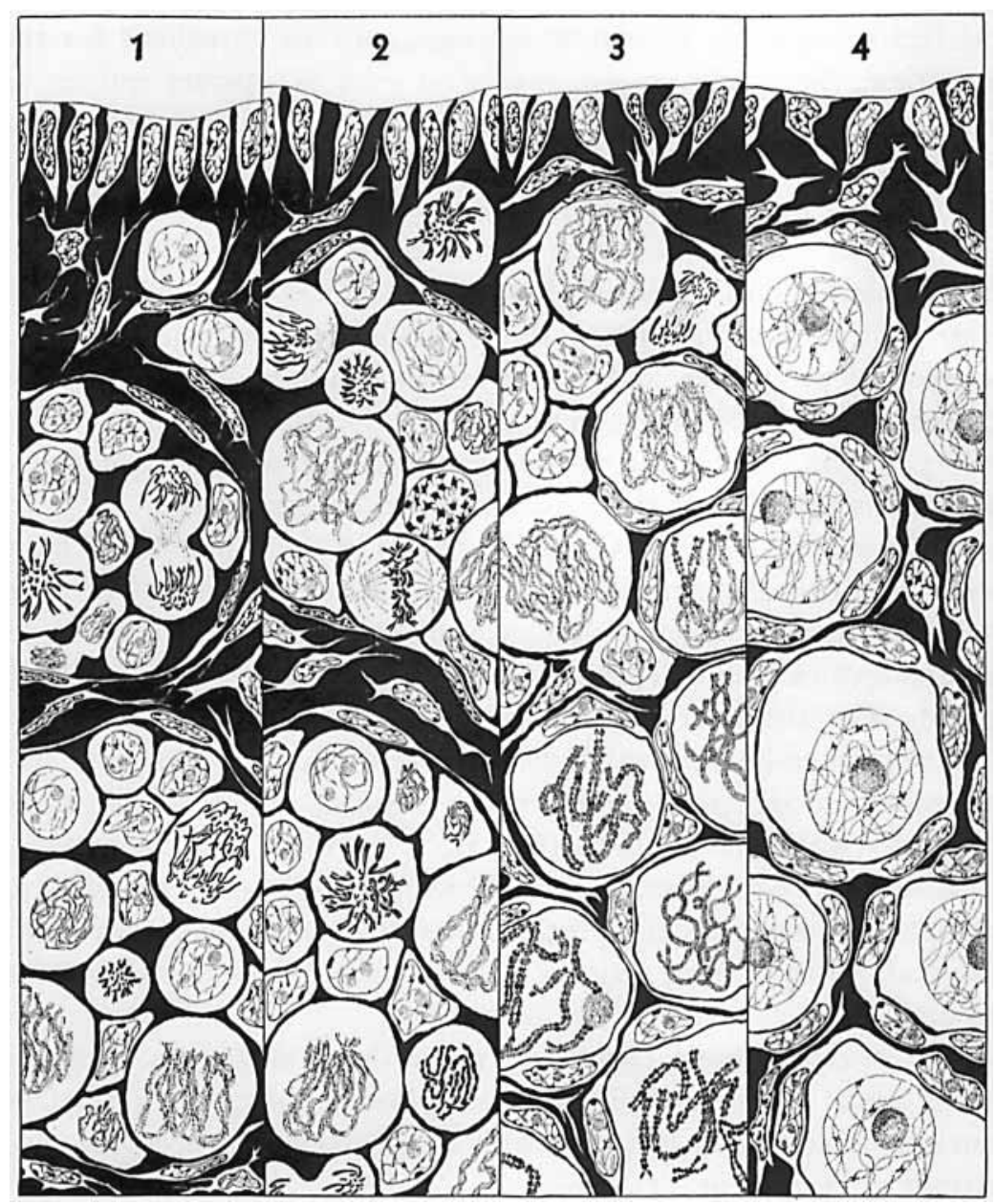

Plate 1. This drawing illustrates the typical histological appearance of the cortical areas of human embryonic ovaries at three months, four months, seven months, and nine months. Size differences between follicular cells, oogonia, and oocytes have been represented as meticulously as possible.

1. In the ovary of a 3-month-old embryo, interphase nuclei of all somatic elements (germinal epithelium, fibroblasts, and follicular cells) are sex-chromatin-positive while those of oogonia are sex-chromatin-negative. Within the ovigerous cords, both follicular cells and oogonia are engaged in vigorous mitotic activity. In the deepest area adjacent to the medulla, a few oocytes in leptotene or zygotene of first meiotic prophase can be observed.

2. In the 4-month-old fetus, active mitosis continues in the germ and somatic cells within the ovigerous cords in the ovary. Many more oocytes are now in leptotene or zygotene. In the upper ovigerous cord, one follicular cell presents a "prochromosome" nucleus.

3. In the 7-month-old fetal ovary, ovigerous cords are no longer distinct, and only follicular elements are undergoing mitosis; no oogonia can be found. At the superficial layer, the oocytes in leptotene and zygotene are not yet closely associated with follicular cells. In the deeper two-thirds of the cortex, however, oocytes in pachytene and diplotene are each surrounded by a monolayer of follicular cells.

4. In the ovary of the 9-month-old fetus, the cortical area is packed with primordial follicles, each containing an oocyte in dictyotene.

(Reproduced from Ohno et al., 1962.)

enjoy riding. I was told of a riding academy which was run by retired Swiss cavalry officers and which all agreed was the best riding academy in Switzerland. It was located near Zürich in the alpine foothills. I telephoned the riding academy to make an appointment and was surprised when they referred me to one of the owners who cross examined me as to Susumu's experience and riding abilities. Since I must have expressed some annoyance at this, the owner explained that they were not the usual type of riding school but specialized in advance training for competition riders and professionals. I outlined Susumu's experience and so he agreed with some reluctance to accept Susumu but told me to tell him that they did not do dressage but did cross country riding, jumping, etc. I relayed this to Susumu and he indicated this was fine. With a 
holiday coming up I made the appointment for a three day period including a weekend. Susumu was very happy with these arrangements and when the appointed time came he set off with clearly happy anticipation of riding in the beautiful alpine foothills.

On the day after his return he arrived late in the laboratory and walked at a slow pace, both of which were unusual for him. When I asked him about his trip, his response was "Strong men, strong horses, these Swiss" and said nothing more. He then set about collecting thick books, set his microscope on them, and proceeded to make his observations standing up.

Understandably I was rather mystified by this but it was clear that he did not want to discuss this further just then. A few days later, after some wine and a good meal, the story finally came out.

The morning after his arrival at the academy he rose shortly after dawn, as he was instructed to do, put on his light dressage riding jodhpurs, thin boots and thin gloves. Shortly thereafter his instructors came with his horse, a broad, heavy and muscular animal very different from the elegant and relatively light dressage horses he was accustomed to. Even more surprising to Susumu was the Swiss army saddle on the horse. These somewhat resemble our western saddles but the seat consists of two ridges of hard wood running in the axis of the horse with an opening between them. Although hard to believe, the Swiss cavalry men claim that these are better suited for long periods in the saddle than are saddles with leather seats.

Off they went at a good pace, up and down the hills, on rocky uneven underage on which the horses maintained an uneven bouncy pace making it hard for Susumu to maintain his usual elegant, steady and smooth post, which added to the difficulty of becoming accustomed to these saddles. Not only did the wooden ridges pound his ischial areas, but his thighs and legs suffered much abuse from the unaccustomed position this type of saddle demanded, and the light dressage jodhpurs and thin boots afforded them little protection, particularly because they soon began to wear thin.

Aside from brief stops at 9:00 A.M. for the traditional Swiss “Z'nüni” which means "to nine o'clock”, a sort of second breakfast which the very early rising hard working Swiss need, and for lunch, this torture continued until the late afternoon. When he returned Susumu discarded his shredded gloves and headed directly to bed. Amazingly he managed to rise again at dawn the next morning. I imagine his instructors must have been surprised at this because I am sure they were aware of the beating he was taking, but neither they nor Susumu gave any indication that anything was amiss. Off they went to the same routine and as Susumu became ever more tired his ability to maintain a good seat in the saddle decreased and the battering increased. The next morning Susumu was awakened by knocking at his door but this time he simply could not get his muscles to respond enough for him to get out of bed. He finally managed to do this in time to get the evening train back to Basel.

It was difficult to determine whether Susumu recovered amazingly fast, or if his strong self control made it seem that way, but he very soon resumed his studies with his usual vigor, and completed the human oogenesis observations and paper in short order (Ohno et al., 1962). This paper was the first accurate description of meiosis in human female embryos, which revealed the then very surprising fact that the oocytes complete the entire process of the first meiotic prophase several weeks before the end of gestation. The oocytes then enter the long, interphase-like dictyotene stage which lasts about 12 years at its shortest, and about 50 years at its longest, leaving a lot of time for environmental and other factors to influence the outcome of the second meiotic division, which is usually completed only after an ovum has been fertilized. This paper became a classic and was cited in many papers and books. I contributed very little to this paper and really did not deserve to be a co-author since I did not even manage to adequately protect Susumu from bodily harm during his visit to Basel.

The figure in that paper illustrating embryonic ovaries at various developmental stages was reproduced in several textbooks and is reproduced here as well (Plate I). The paper appeared 1962 in the first issue of the first volume of Cytogenetics which was the name of Cytogenetics and Cell Genetics up to 1973. The figure was drawn by Susumu and demonstrates not only his keen abilities at making observations but also his fine artistic talents which served him very well in his scientific work.

References

Ohno S, Kaplan WD, Kinosita R: On the end-to-end association of the $\mathrm{X}$ and $\mathrm{Y}$ chromosomes of $\mathrm{Mus}$ musculus. Exp Cell Res 18:282-290 (1959).

Ohno S, Kaplan WD, Kinosita R: X-chromosome behavior in germ and somatic cells of Rattus norvegicus. Exp Cell Res 22:535-544 (1961a).
Ohno S, Makino S, Kaplan WD, Kinosita R: Female germ cells of man. Exp Cell Res: 24:106-110 (1961b).

Ohno S, Klinger HP, Atkin NB: Human Oogenesis. Cytogenetics 1:42-51 (1962). 